\title{
SERUM LEVELS OF OXIDATIVE STRESS PARAMETERS IN POSTMENOPAUSAL VERSUS FERTILE WOMEN OF KUTAHYA CITY, TURKEY
}

\author{
Behic Selman Erdogdu', Mustafa Yontem², Fatma Emel Kocak ${ }^{3}$, Hayrullah Yazar ${ }^{4}$ \\ Departments of ${ }^{1}$ Molecular Biology and Genetics \& ${ }^{2}$ Biotechnology, Faculty of Science, Necmettin Erbakan \\ University, Meram, Konya, ${ }^{3}$ Department of Biochemistry, Faculty of Medicine, Kutahya University of Health \\ Sciences, Kutahya ${ }^{4}$ Department of Medical Biochemistry, Faculty of Medicine, Sakarya University, Sakarya, \\ Turkey
}

\begin{abstract}
Background: Decreased concentration of both oestrogen hormone and vitamin $D$ in postmenopausal period may lead to oxidative stress, lipid peroxidation, dyslipidaemia, osteoporosis, and cardiovascular diseases. The objectives of this study were to determine and compare the serum levels of oxidative stress parameters; TOS, TAS, OSI, PON-1, ARYL in postmenopausal and fertile women of Kutahya city, Turkey.

Materials \& Methods: This cross-sectional study was conducted at Department of Biochemistry, Faculty of Medicine, Kutahya University of Health Sciences, Kutahya, Turkey from July, 2016 to December, 2016. Kutahya is a city in western Turkey, with population of 237,804 as per 2011 estimates. Two samples were drawn from this population with consecutive technique. Study group included 40 menopausal women, while control group included 40 healthy fertile women. After overnight fasting, venous blood samples were collected, centrifuged, aliquoted into a polystyrene tube, and aliquots were stored at $-80^{\circ} \mathrm{C}$ until measurement for total oxidant status (TOS), total antioxidant status (TAS), paraoxonase-1 (PON-1), and arylesterase (ARYL) measurements were made. Levels of TOS, TAS, OSI, PON-1, ARYL were five research variables on ratio scale. 'Normal' data were described by mean, range and SD and skewed data by median, Q1, Q3 and IQR with 95\% confidence intervals. For normal data, independent-samples t-test and for skewed data Mann-Whitney $U$ test was used for hypotheses testing.

Results: Serum total oxidant status (TOS) and oxidative stress index (OSI) levels were significantly higher ( $p$-value $.015 \& .003$ respectively), and serum paraoxonase-1 (PON-1) and arylesterase (ARYL) levels were significantly lower in postmenopausal than fertile women ( $p$-value $<.0001 \& .0005$ respectively), with no statistical difference for serum total antioxidant status (TAS) levels between the two groups ( $p$-value .186).

Conclusion: Postmenopausal period is associated with oxidative stress and decreased antioxidant defence. HDLc-dependent PON-1 and ARYL activities are also reducing due to a decrease of HDL-c with menopause. Elevated levels of TOS and OSI, decreased levels of PON-1 and ARYL may lead to various life-threatening diseases such as cardiovascular disorders or cancer.
\end{abstract}

KEY WORDS: Antioxidants; Menopause; Postmenopause; Postmenopausal Period; Oxidative Stress; Arylesterase; Paraoxonase-1; Women.

Cite as: Erdogdu BS, Yontem M, Kocak FE, Yazar H. Serum levels of oxidative stress parameters in postmenopausal versus fertile women of Kutahya city, Turkey. Gomal J Med Sci 2021 Jan-Mar; 19(1):19-27. https://doi.org/10.46903/gjms/19.01.934

\section{Corresponding Author:}

Dr. Fatma Emel Kocak

Associate Professor

Department of Biochemistry, Faculty of Medicine Kutahya University of Health Sciences, Kutahya, Turkey

E-mail: fatmaemel.kocak@ksbu.edu.tr

Date Submitted:

03-06-2020

Date Revised:

Date Accepted:
28-12-2020
19-09-2020

\section{INTRODUCTION}

1.1. Background: Menopause is described as the permanent cessation of menstrual cycles. It is characterized by the increased risk of cardiovascular diseases and osteoporosis due to abrupt drop of oestrogen levels in women. Therefore, it might be considered as a transitional period to the aging process with its own classical signs and symptoms. ${ }^{1-4}$ When changes in cycle frequency or in menstrual flow are primely observed during the menopausal transition; both gonadotropins, oestradiol and 
inhibin, show a marked degree of variability with rapid changes from typical post-menopausal patterns to those characteristics in the reproductive term. In postmenopausal women, inhibin and oestradiol levels were significantly decreased or undetectable while $\mathrm{FSH}$ levels were increased. ${ }^{5}$

Aerobic life is accompanied by the constant formation of reactive oxygen species (ROS), which are known to play a dual role as both harmful and beneficial properties. Due to their highly toxic and destructive nature, they are crucial in normal metabolic reactions and defence system. ${ }^{6}$ Besides their beneficial effects; ROS, which are produced by the immune system in inflammatory reactions, may react each other and produce more free radicals which are potential oxidizing agents that can cause lipid peroxidation and DNA fragmentation. ${ }^{7}$ Oestrogen is a phenolic compound and it has structural similarities with lipophilic antioxidant a-tocopherol, thus, the similarity of them enables the molecule to detoxify accumulated ROS and act as an antioxidant. ${ }^{8}$ High concentration levels of oestrogen provides a significant antioxidant effect by inhibiting the 8-hydroxylation of guanine DNA bases, whereas the low concentration levels of oestrogen (especially when the structure contains catechol) has a prooxidants-like activity such as breaks in genetic material, formation of DNA adducts, and oxidation of bases. ${ }^{9}$ Oxidative stress can cause deactivation of some metabolic pathways and defects in genetic materials, which may result in various diseases such as cardiovascular disorders and different types of cancer. In addition to endogenous oxygen metabolism, ROS is produced secondarily by a variety of environmental agents and have been considered as responsible for the aging, menopause, and osteoporosis. ${ }^{6,10,11}$ It has been reported that menopause is associated with an increase in oxidative stress and a decrease in some antioxidant species. ${ }^{11,12}$

Paraoxonases were originally discovered as enzymes that hydrolyse exogenous toxic organophosphate compounds such as insecticide or nerve gas. The paraoxonases family currently consists of three members: PON-1, PON-2 and PON-3; which are encoded by three separate genes located between q21.3 and q22.1 on the long arm of chromosome 7 in humans. ${ }^{13,14}$ Both PON-1 and PON-3 are associated with $\mathrm{HDL}$-c and present anti-inflammatory and antioxidant properties. PON-2 and PON-3 are intracellular enzymes that modulate mitochondrial superoxide anion production and endoplasmic reticulum stress-induced apoptosis. ${ }^{15} \mathrm{PON}-1$ is a calcium-dependent enzyme that consists of 354 amino acids with molecular mass $43 \mathrm{kDa}$ and synthesized and secreted by liver. ${ }^{16,17}$ It resides on HDL-C and protects against the oxidative modification of HDL-C and LDL-c by hydrolysing lipid peroxides.
PON-1 binds tightly to HDL subfractions which are containing apoA-1 and apoJ or clusterin and is capable to protect LDL-C from oxidation. Oxidation of LDL-c plays an important role in the development and progression of atherosclerotic lesion. PON-1 inhibits HDL-C and LDL-C oxidation and maintains their functions. ${ }^{17}$ Moreover, PON-1 esterase acts as an important component of the enzymatic antioxidant system with arylesterase (ARYL) having the same functions. ${ }^{18}$ In result of increased lipid profile and cardiovascular risk, the investigation of PON-1 and ARYL activities in postmenopausal women is crucial.

Although numerous studies have been performed in this area, as far as our knowledge, this paper is the first study that combines studied parameters.

1.2 Research Problems (RPs), Knowledge Gaps (KGs), Rationale \& Research Questions (RQs): Serum levels of five oxidative stress parameters; TOS, TAS, OSI, PON-1, ARYL in postmenopausal and fertile women of Kutahya city, Turkey are not known to us. This unawareness of five pieces of information are our five KGs. To fill these five gaps is the rational of our study. What would be the serum levels of these five parameters in our population are our five RQs.

\subsection{Research Objectives (ROs)}

RO 1-5: To determine the serum levels of oxidative stress parameters; TOS, TAS, OSI, PON-1, ARYL in postmenopausal and fertile women of Kutahya city, Turkey.

RO 6-10: To compare the serum levels of oxidative stress parameters; TOS, TAS, OSI, PON-1, ARYL in postmenopausal and fertile women of Kutahya city, Turkey.

\subsection{Research (Null) Hypotheses (RHs):}

$\mathbf{H}_{01}$ : There is statistically no significant difference in the serum levels of TOS in postmenopausal and fertile women of Kutahya city, Turkey. (RQ 6)

$\mathbf{H}_{02}$ : There is statistically no significant difference in the serum levels of TAS in postmenopausal and fertile women of Kutahya city, Turkey. (RQ 7)

$\mathbf{H}_{03}$ : There is statistically no significant difference in the serum levels of OSI in postmenopausal and fertile women of Kutahya city, Turkey. (RQ 8)

$\mathbf{H}_{04}$ : There is statistically no significant difference in the serum levels of $\mathrm{PON}-1$ in postmenopausal and fertile women of Kutahya city, Turkey. (RQ 9)

$\mathbf{H}_{05}$ : There is statistically no significant difference in the serum levels of ARYL in postmenopausal and fertile women of Kutahya city, Turkey. (RQ 10)

1.5 Significance: With information in hand, we can formulate local guidelines for diagnosis and management of menopausal symptoms in women.

\section{MATERIAL AND METHODS}

2.1 Design, Duration \& Setting: This cross-sec- 
tional study was carried out at the Department of Biochemistry, Faculty of Medicine, Kutahya University of Health Sciences, Kutahya, Turkey from July, 2016 to December, 2016. The samples were selected from the Department of Medical Biochemistry, Evliya Celebi Research and Education Hospital, Kutahya, The guidelines of the Declaration of Helsinki were followed. Ethical committee approval was granted by the local Human Research Ethics Committee. Written informed consent was obtained from all the subjects.

2.2 Population, Sample Size \& Technique and Selection: Kutahya is a city in western Turkey, with population of 576,688 as per year 2020 estimates. The sample size calculation was based on arylesterase (ARYL) levels. With presumed mean \& SD levels of $548 \pm 90$ for menopausal women (group 1) and $625 \pm 110$ for fertile women (group 2), with difference of $-77(\mathrm{U} / \mathrm{L})$, ratio of sample size (group 2/ group 1) as 1, confidence level $99 \%$ and power $80 \%$, the sample size was calculated as 40 for each group, with total 80 , through an online sample size calculator "OpenEpi", available at: https://www. openepi.com/SampleSize/SSMean.htm

Two samples were drawn from this population with consecutive non-probability technique. Group 1 (study group) included 40 menopausal women (no menses for at least 12 months), who had never used a hormone replacement therapy, while group 2 (control group) included 40 healthy fertile women with regular menses. Women with alcoholism, smoking, existence of chronic medical illnesses (heart failure, hypertension, renal failure, diabetes mellitus, autoimmune diseases, respiratory diseases, cerebral failure, and peripheral vascular diseases), chronic pharmacological therapy, use of supplemental multivitamins, minerals, and antioxidants, with capability of interfering oxidant-antioxidant balance, were excluded from both the groups.

\subsection{Conduct of procedure for blood sample col-} lection and laboratory testing

\subsubsection{Blood sample collection}

After overnight fasting, venous blood samples were collected and centrifuged at $\times 1500 \mathrm{~g}$ for 15 mins to obtain serum samples. The serum samples were aliquoted into a polystyrene tube, and aliquots were stored at $-80^{\circ} \mathrm{C}$ until total oxidant status (TOS), total antioxidant status (TAS), paraoxonase-1 (PON-1), and arylesterase (ARYL) measurements were made.

\subsubsection{Measurement of serum TOS and TAS levels}

Serum TOS and TAS levels were measured using a Beckman Coulter AU680 instrument (Beckman Coulter, Miami, FL, USA) with commercial reagents (Rel Assay Diagnostic, Gaziantep, Turkey). The methods was based on novel automated measurement methods developed by Erel. ${ }^{19,20}$ TOS levels were expressed as $\mu \mathrm{mol} \mathrm{H}_{2} \mathrm{O}_{2}$ equivalent/L. TAS levels were expressed as $\mathrm{mmol}$ Trolox equivalent/L.

\subsubsection{Calculation of oxidative stress index (OSI)}

The percent ratio of TOS to TAS was accepted as the OSI, an indicator of the degree of oxidative stress. To TAS in mmol Trolox equivalent/L was converted to $\mu \mathrm{mol}$ Trolox equivalent/L, after which the OSI was calculated as follows: $\mathrm{OSI}=\left[\left(\mathrm{TOS}, \mu \mathrm{mol} \mathrm{H}_{2} \mathrm{O}_{2} \mathrm{Eq} / \mathrm{L}\right)\right.$ / (TAS, $\mu \mathrm{mol}$ Trolox Eq/L) $\times 100]$. The results are expressed as arbitrary units (AU).

\subsubsection{Measurement of serum PON-1 and ARYL activities}

Serum PON-1 and ARYL activities were measured on a Beckman Coulter AU680 instrument (Beckman Coulter, Miami, FL, USA) using commercial assay reagents (Rel Assay Diagnostic, Gaziantep, Turkey). The methods were based on automated measurement methods..$^{21}$ Serum PON-1 and ARYL activities were expressed as $\mathrm{U} / \mathrm{L}$.

\subsection{Data Collection \& Data Analysis Plan}

2.4.1 Descriptive Statistics \& Estimation of Parameters: Levels of TOS, TAS, OSI, PON-1, ARYL were our five research variables. The data type for these variables was on ratio (numeric) scale. The data for all these variables were subjected to tests of normality; skewness, kurtosis, CV\% and Shapiro-Wilk test. If normal, were described by mean, minimum, maximum, range and standard deviation, otherwise described by median (Q2), Q1 (quartile), Q3 and IQR (Q3-Q1) for each group separately for the sample. Estimated parameters for population were given as confidence intervals $(\mathrm{Cl})$ of mean or of median at $95 \%$ confidence level $(\mathrm{CL})$. Descriptively, the difference between the groups is based on comparing their confidence intervals (Cls), not their means or medians. If there is overlap of Cls, the levels are similar; otherwise different; lower or higher, as the case may be.

2.4.2 Hypotheses Testing: For variables with normally distributed data, parametric test independentsamples t-test (two tailed) was used for comparison, giving sample size, mean, SD, mean difference, $\mathrm{Cl}$ of mean difference, degree of freedom, t-value and significance ( $p$-value) at alpha .05. For variables with not normally distributed (skewed) data, nonparametric statistical test Mann-Whitney $U$ test was used for comparison, giving median, interquartile ranges (IQRs), difference between medians, MannWhitney U, Wilcoxon $W, Z$, and significance ( $p$-value). The data were analysed by SPSS version 16.0 (SPSS Inc., Chicago, IL, USA) for Windows.

\section{RESULTS}

3.1 Tests of normality: The results are shown in Table 3.1, with interpretation based on the four tests. All variables are interpreted as skewed except ARYL as 'Normal'.

3.2 Descriptive Statistics \& Estimation of Parameters: Table 3.2.1 shows sample statistics and 
population parameters for the four skewed data variables. Based on their confidence intervals (Cls), the median levels of TOS, TAS and OSI are similar in postmenopausal women and fertile women, as there is overlapping of their Cls. The median level of PON-1 is lower in postmenopausal women than fertile women, as there is no overlapping of their Cls. These differences between the two groups are only true descriptively. True/ real differences are shown by the hypotheses testing in next step.
Table 3.2.2 shows sample statistics and population parameters for one normal data variable; ARYL. The mean level of ARYL is lower in postmenopausal women than fertile women, as there is no overlapping of their Cls. This difference between the two groups is only true descriptively. True/ real difference is shown by the hypothesis testing in next step.

\subsection{Hypotheses Testing}

3.3.1 TOS level in postmenopausal versus fertile

Table 3.1: Tests of normality for five oxidative stress variables in postmenopausal $(n=40)$ and fertile $(n=40)$ women of Kutahya city, Turkey

\begin{tabular}{|l|l|c|c|c|c|c|c|}
\hline Variables & Group (women) & Skewness & Kurtosis & CV \% & W & p-value & $\begin{array}{c}\text { Data distri- } \\
\text { bution }\end{array}$ \\
\hline \multirow{2}{*}{$\begin{array}{c}\text { TOS } \\
\left(\mu \mathrm{mol} \mathrm{H} \mathrm{O}_{2} \text { Eq./L) }\right.\end{array}$} & Postmenopausal & 2.650 & 8.56 & 64.38 & 0.716 & $<.0001$ & Skewed \\
\cline { 2 - 8 } & Control & 3.012 & 12.23 & 52.77 & 0.716 & $<.0001$ & Skewed \\
\hline \multirow{2}{*}{$\begin{array}{c}\text { TAS } \\
\text { Trmol Trolox Eq./L) }\end{array}$} & Postmenopausal & 0.789 & -0.131 & 10.20 & 0.930 & .016 & Skewed \\
\cline { 2 - 8 } & Control & 0.242 & -0.962 & 8.96 & 0.960 & .174 & Normal \\
\hline \multirow{2}{*}{$\begin{array}{l}\text { OSI } \\
\text { Arbitrary Unit) }\end{array}$} & Postmenopausal & 2.550 & 8.23 & 59.73 & 0.730 & $<.0001$ & Skewed \\
\cline { 2 - 8 } & Control & 1.025 & 1.49 & 37.05 & 0.922 & .009 & Skewed \\
\hline \multirow{2}{*}{ PON-1 (U/L) } & Postmenopausal & 1.638 & 1.783 & 60.84 & 0.766 & $<.0001$ & Skewed \\
\cline { 2 - 8 } & Control & 0.514 & -0.050 & 49.53 & 0.947 & .059 & Normal \\
\hline
\end{tabular}

CV\% = Coefficient of variation \%, W= Shapiro-Wilk Statistic

Table 3.2.1: Descriptive statistics \& population parameters for four skewed oxidative stress variables in postmenopausal $(n=40)$ and fertile $(n=40)$ women of Kutahya city, Turkey

\begin{tabular}{|c|c|c|c|c|c|c|c|}
\hline \multirow[b]{2}{*}{ Variables } & \multirow[b]{2}{*}{ Groups (women) } & \multicolumn{4}{|c|}{ Sample statistics } & \multicolumn{2}{|c|}{$95 \% \mathrm{Cl}$ for median } \\
\hline & & $\begin{array}{c}\text { Quartile 1 } \\
\text { (Q1) }\end{array}$ & $\begin{array}{l}\text { Median } \\
\text { (Q2) }\end{array}$ & $\begin{array}{c}\text { Quartile } \\
3 \text { (Q3) }\end{array}$ & IQR & Lower & Upper \\
\hline \multirow{2}{*}{$\begin{array}{l}\text { TOS } \\
\left(\mu \mathrm{mol} \mathrm{H}_{2} \mathrm{O}_{2} \text { Eq./L) }\right.\end{array}$} & Postmenopausal & 4.71 & 6.450 & 8.19 & 3.48 & 5.420 & 7.590 \\
\hline & Fertile & 3.71 & 4.965 & 6.54 & 2.84 & 4.250 & 5.870 \\
\hline \multirow{2}{*}{$\begin{array}{l}\text { TAS } \\
\text { (mmol Trolox Eq./L) }\end{array}$} & Postmenopausal & 1.463 & 1.565 & 1.698 & 0.24 & 1.490 & 1.650 \\
\hline & Fertile & 1.510 & 1.655 & 1.740 & 0.23 & 1.550 & 1.700 \\
\hline \multirow{2}{*}{$\begin{array}{l}\text { OSI } \\
\text { (Arbitrary Unit) }\end{array}$} & Postmenopausal & 0.315 & 0.435 & 0.480 & 0.16 & 0.340 & 0.460 \\
\hline & Fertile & 0.223 & 0.315 & 0.398 & 0.18 & 0.250 & 0.380 \\
\hline \multirow{2}{*}{ PON-1 (U/L) } & Postmenopausal & 94.8 & 118.5 & 171.3 & 76.5 & 102.0 & 137.0 \\
\hline & Fertile & 167.3 & 336.5 & 449.3 & 282 & 2820 & 363.0 \\
\hline
\end{tabular}

$\mathrm{Q}=$ Quartile, $\mid \mathrm{QR}=$ Inter quartile range (Q3-Q1), $\mathrm{Cl}=$ Confidence Interval

Table 3.2.2: Descriptive statistics \& estimation of parameters for one normal oxidative stress variable; ARYL in postmenopausal $(n=40)$ and fertile women $(n=40)$ of Kutahya city, Turkey

\begin{tabular}{|l|l|c|c|c|c|c|c|c|}
\hline \multirow{2}{*}{ Variable } & \multirow{2}{*}{ Group (women) } & \multicolumn{4}{|c|}{ Sample Statistics } & \multicolumn{3}{c|}{$95 \%$ Cl of Mean } \\
\cline { 3 - 9 } & & Mean & Min. & Max. & Range & SD & Lower & Upper \\
\hline \multirow{2}{*}{ ARYL (U/L) } & Postmenopausal & 553.5 & 264.0 & 838.0 & 574 & 101.7 & 521.0 & 586.0 \\
\cline { 2 - 9 } & Fertile & 643.8 & 428.0 & 856.0 & 428 & 118.7 & 605.9 & 681.8 \\
\hline
\end{tabular}

$\mathrm{n}=$ Sample size, $\mathrm{SD}=$ Standard deviation, $\mathrm{Cl}=$ Confidence interval 
women $\left(\mathbf{H}_{01}\right)$ : The serum TOS level was compared through Mann Whitney $U$ test at alpha .05. With p-value less than $.05, \mathrm{H}_{01}$ was proved to be false and hence rejected, showing the difference to be statistically significant. İ simple words, serum TOS level was higher in postmenopausal women than fertile women. (Table 3.3.1)

3.3.2 TAS level in postmenopausal versus fertile women $\left(\mathrm{H}_{02}\right)$ : The serum TAS level was compared through Mann Whitney $U$ test at alpha .05. With p-value more than $.05, \mathrm{H}_{02}$ could not be proved as false (was true) and hence accepted, showing the difference is not statistically significant. İ simple words, serum TAS level was similar in postmenopausal and fertile women. (Table 3.3.2)

3.3.3 OSI level in postmenopausal versus fertile women $\left(\mathrm{H}_{03}\right)$ : The serum OSI level was compared through Mann Whitney U test at alpha .05. With p-value less than .05, $\mathrm{H}_{03}$ was proved as false and hence rejected, showing the difference is statistically significant. İn simple words, serum OSI level was higher in postmenopausal than fertile women. (Table 3.3.3)

3.3.4 PON-1 level in postmenopausal versus fertile women $\left(\mathrm{H}_{04}\right)$ : The serum PON-1 level was compared through Mann Whitney $U$ test at alpha .05. With p-value less than $.05, \mathrm{H}_{04}$ was proved as false and hence rejected, showing the difference is statistically significant. In simple words, serum PON-1 level was lower in postmenopausal than fertile women. (Table 3.3.4)

3.3.5 ARYL level in postmenopausal versus fertile women $\left(\mathrm{H}_{05}\right)$ : The serum ARYL level was compared through independent samples t-test at alpha .05. With $\mathrm{p}$-value less than $.05, \mathrm{H}_{05}$ was proved as false and hence rejected, showing the difference is statistically significant. İ simple words, serum ARYL level was lower in postmenopausal than fertile women. (Table 3.3.5)

Table 3.3.1: TOS ( $\mu \mathrm{mol} \mathrm{H2O2} \mathrm{Eq./L)} \mathrm{level} \mathrm{in} \mathrm{postmenopausal} \mathrm{versus} \mathrm{fertile} \mathrm{women} \mathrm{of} \mathrm{Kutahya} \mathrm{city,} \mathrm{Tur-}$ key

\begin{tabular}{|c|c|c|c|c|c|c|c|}
\hline Groups & Median & IQRs & $\begin{array}{l}\text { Difference } \\
\text { of medians }\end{array}$ & $\begin{array}{c}\text { Mann- } \\
\text { Whitney U }\end{array}$ & Wilcoxon W & Z & $\begin{array}{c}\text { p-value } \\
\text { (2-tailed) }\end{array}$ \\
\hline Postmenopausal $(n=40)$ & 6.450 & & \multirow{2}{*}{1.485} & 546.5 & 1366.5 & -2.439 & .015 \\
\hline Control $(n=40)$ & 4.965 & $3.71-6.54$ & & \multicolumn{2}{|c|}{ Mann Whitney U test } & \multicolumn{2}{|c|}{$\mathrm{H}_{01}$ rejected at a 0.05} \\
\hline
\end{tabular}

Table 3.3.2: TAS (mmol Trolox Eq./L) level in postmenopausal versus fertile women of Kutahya city, Turkey

\begin{tabular}{|c|c|c|c|c|c|c|c|}
\hline Groups (women) & Median & IQRs & $\begin{array}{l}\text { Difference } \\
\text { of medians }\end{array}$ & $\begin{array}{c}\text { Mann- } \\
\text { Whitney U }\end{array}$ & Wilcoxon W & Z & $\begin{array}{c}\mathrm{p} \text {-value } \\
\text { (2-tailed) }\end{array}$ \\
\hline Postmenopausal $(n=40)$ & 6.450 & $1.46-1.10$ & \multirow{2}{*}{-0.09} & 662.0 & 1482.000 & -1.328 & .186 \\
\hline Control $(n=40)$ & 4.965 & $1.51-1.74$ & & Mann W & ney U test & \multicolumn{2}{|c|}{$\mathrm{H}_{02}$ accepted at a 0.05} \\
\hline
\end{tabular}

Table 3.3.3: OSI (Arbitrary Unit) level in postmenopausal versus fertile women of Kutahya city, Turkey

\begin{tabular}{|c|c|c|c|c|c|c|c|}
\hline Groups (women) & Median & IQRs & $\begin{array}{l}\text { Difference } \\
\text { of medians }\end{array}$ & $\begin{array}{c}\text { Mann- } \\
\text { Whitney U }\end{array}$ & Wilcoxon W & Z & $\begin{array}{c}\text { p-value } \\
\text { (2-tailed) }\end{array}$ \\
\hline Postmenopausal $(n=40)$ & 0.435 & $0.32-0.48$ & \multirow{2}{*}{0.120} & 497.500 & 1317.500 & -2.913 & .003 \\
\hline Control $(n=40)$ & 0.315 & $0.22-0.40$ & & Mann Wh & tney U test & \multicolumn{2}{|c|}{$\mathrm{H}_{03}$ rejected at a 0.05} \\
\hline
\end{tabular}

Table 3.3.4: PON-1 (U/L) level in postmenopausal versus fertile women of Kutahya city, Turkey

\begin{tabular}{|c|c|c|c|c|c|c|c|}
\hline Groups (women) & Median & IQRs & $\begin{array}{l}\text { Difference } \\
\text { of medians }\end{array}$ & $\begin{array}{c}\text { Mann- } \\
\text { Whitney U }\end{array}$ & Wilcoxon W & Z & $\begin{array}{c}\text { p-value } \\
\text { (2-tailed) }\end{array}$ \\
\hline Postmenopausal $(n=40)$ & 118.5 & $94.75-171.3$ & \multirow{2}{*}{218} & 242.5 & 1062.5 & -5.365 & $<.0001$ \\
\hline Control $(n=40)$ & 336.5 & $167.3-449.3$ & & Mann Wh & tney $U$ test & \multicolumn{2}{|c|}{$\mathrm{H}_{04}$ rejected at a 0.05} \\
\hline
\end{tabular}

Table 3.3.5: ARYL (U/L) level in postmenopausal versus fertile women of Kutahya city, Turkey

\begin{tabular}{|c|c|c|c|c|c|c|c|c|}
\hline \multirow{2}{*}{ Group (women) } & \multirow{2}{*}{ Mean } & \multirow{2}{*}{ SD } & \multirow{2}{*}{$\begin{array}{l}\text { Difference } \\
\text { of means }\end{array}$} & \multicolumn{2}{|c|}{$95 \% \mathrm{Cl}$ of difference } & t-value & d.f. & $\begin{array}{l}\text { p-value } \\
\text { (2-tailed) }\end{array}$ \\
\hline & & & & Lower & Upper & \multirow{2}{*}{-3.654} & \multirow{2}{*}{78} & \multirow{2}{*}{.0005} \\
\hline Postmenopausal $(n=40)$ & 553.5 & 101.7 & -90.33 & 41.11 & 139.5 & & & \\
\hline Control $(n=40)$ & 643.8 & 118.7 & \multicolumn{3}{|c|}{ Independent-samples t-test } & \multicolumn{3}{|c|}{$\mathrm{H}_{05}$ rejected at a 0.05} \\
\hline
\end{tabular}

$\mathrm{n}=$ Sample size, $\mathrm{SD}=$ Standard deviation, $\mathrm{d} . \mathrm{f} .=$ Degree of freedom 


\section{DISCUSSION}

4.1 TOS levels in postmenopausal versus fertile women $\left(\mathrm{H}_{01}\right)$ : Our study showed serum TOS levels higher in postmenopausal women than fertile women. (Table 3.3.1) Accordingly, a study ${ }^{22}$ conducted in Sanliurfa, Turkey, and a middle-European study ${ }^{23}$ revealed that serum TOS levels were significantly higher in postmenopausal women. Additionally, Zhao et al. ${ }^{24}$ recently reviewed 36 studies from different regions, and as a result overall of their investigation, they claimed that there were no statistically significant differences in TOS levels of postmenopausal women with osteoporosis compared to healthy controls.

4.2 TAS level in postmenopausal versus fertile women $\left(\mathbf{H}_{02}\right)$ : Our study showed serum TAS levels similar in postmenopausal and fertile women. (Table 3.3.2) Although TAS levels of postmenopausal group were slightly lower than healthy controls, any statistical significance was not detected. Our findings were in agreement with the studies of Dikker, et al. ${ }^{25}$ (Corum and Istanbul, Turkey) and Klisic et al. ${ }^{23}$ (Montenegro and Serbia). However; Altindag et al. ${ }^{22}$ (Sanliurfa, Turkey), Zovari, et al. ${ }^{26}$ (Babol, Iran), Bednarek-Tupikowski, et al. ${ }^{27}$ (Wroclaw, Poland), and Kolesnikova et al. ${ }^{28}$ (Irkutsk, Russia) have found that serum TAS levels were significantly decreased in postmenopausal women. A decreased serum TAS activity is also reported in the review by Zhao, et al. ${ }^{24}$ The reason for these differences might be related to various conditions such as dietary habits, milieu, regional variations, or hereditary specifications.

4.3 OSI level in postmenopausal versus fertile women $\left(\mathrm{H}_{03}\right)$ : Our study showed serum OSI levels higher in postmenopausal than fertile women. (Table 3.3.3) Our findings are in accordance with the studies of Altindag et al. ${ }^{22}$ (Sanliurfa, Turkey), Klisic et al. ${ }^{23}$ (Montenegro and Serbia), and Zhao et al. ${ }^{24}$ Vassalle et al. ${ }^{29}$ (Pisa, Italy) investigated the effects of sex in coronary artery disease with association of oxidative stress and reported that women (all of them were postmenopausal) had three times higher oxidative stress compared to men.

Oxidative stress is strongly correlated with atherogenic index of plasma in cardiovascular disease and it is thought as an effective prognostic tool for early detection of cardiovascular risk in menopause. ${ }^{9}$ OSI could be calculated with a number of methods and different parameters except used in this study. Investigation of OSI might be helpful to predict other possible metabolic disorders which are related to oxidative stress and deficiency of antioxidant defence system.

In the postmenopausal period, the protective effect of HDL-c to cardiovascular diseases tends to lose. ${ }^{27}$ Some researchers have reported that any significant decrease were not observed on HDL-c levels, ${ }^{31-33}$ whereas majority of previous studies stated that HDL-c levels are tended to decrease during menopausal transition and postmenopausal period. ${ }^{34-38}$ PON-1 and PON-3 are esterases associated with HDL-c particle which hydrolyses arylesters, organophosphates, proinflammatory oxidized lipids present in oxidized LDL-C, and lipid peroxides in atherosclerotic lesions in association with ARYL and lactonase activity. ${ }^{39,40}$ Several studies have previously reported that PON-1 and ARYL activities reduced with either surgical or natural menopause. ${ }^{17,40,41}$

4.4 PON-1 level in postmenopausal versus fertile women $\left(\mathrm{H}_{04}\right)$ : Our study showed serum PON-1 levels lower in postmenopausal than fertile women. (Table 3.3.4) In a study, which investigated the oxidative stress in postmenopausal osteoporotic women in Kayseri, ${ }^{42}$ Turkey, it was stated that PON-1 activity was found lower compared to healthy subjects. As far to our knowledge, the literature has tended to focus mostly on changes in PON-1 levels as a result of hormone replacement therapy in postmenopausal women. It has shown that hormone replacement therapy reduced the levels of oxidized LDL-C and increased PON-1 activity in postmenopausal women. ${ }^{41}$ However, a study performed with the participation of 30 postmenopausal and 28 premenopausal healthy women (Buenos Aires, Argentina) reported that PON-1 activity did not show difference between both of the study groups. ${ }^{43}$ In another study (Izmir, Turkey) on patients with acute coronary syndrome, it was reported that decreased serum PON-1 activity has been associated with increased oxidative stress and PON-1 activity was not connected to HDL-c. ${ }^{44}$ Interestingly, an American study that investigated the comparison of HDL-c levels in African-American and white American non-diabetic postmenopausal women declared that African-American women represent significantly lower PON-1 activity, although HDL-C levels are higher than white American women. ${ }^{45}$

4.5 ARYL level in postmenopausal versus fertile women $\left(\mathrm{H}_{05}\right)$ : Our study showed serum ARYL levels lower in postmenopausal than fertile women. (Table 3.3.5) As activities of ARYL and PON-1 are related, studies are mostly focused on the changes after the hormone replacement therapy in postmenopausal women. Similar to our findings, Sutherland et al. ${ }^{39}$ (Dunedin, New Zealand) reported that serum $\mathrm{PON}-1$ arylesterase activity was significantly lower, but it has significantly increased after the hormone replacement therapy in the postmenopausal diabetic women. Interestingly, Butorac et al. ${ }^{46}$ (Zagreb, Croatia) reported that there were no statistically significant difference in the ARYL activity among premenopausal and postmenopausal women.

So far, however, there has been little evidence about the activities of PON-1 and ARYL in postmenopausal women in the literature. We modestly acknowledge that this study meets an important deficit by profiling 
oxidative stress status in postmenopausal women.

\subsection{Strengths of our study}

4.6.1 Marwat's Logical Trajectory of Research Process: We have followed this 8-steps intellectual and logical flow of identifying our research problems, ascertaining the knowledge gaps; if there, narrating our problems as research questions, formulating them as objectives, collecting tentative answers for our questions from literature as hypotheses, collecting data for relevant variables from our sample, analysing and interpreting these data to get answers for our questions; thus filling our knowledge gaps and solving our problems. ${ }^{47-49}$

4.6.2 Population-Sample-Population Flow: Research is a systematic (step-by-step) process (never ending activity) aiming to solve the problems for a specified population. But many studies in global literature are seen, starting from the sample and ending on the sample, with no mention of their specified population/ population of interest/ population at risk. We have specified our population, have drawn the sample, collected \& interpreted the data for the sample and then inferred it to our population as estimation of parameters and hypotheses testing, thus answering the questions and solving the problems regarding our population. ${ }^{47-49}$

\section{CONCLUSION}

The most obvious finding to emerge from this study is that menopause leads to changes in the body by increasing oxidative profile and decreasing antioxidant defence in relation with reduced HDL-c profile. These changes increase the risk for metabolic disorders such as cardiovascular diseases, osteoporosis, diabetes mellitus, and cancer. The decrease of HDL-C may lead to cardiovascular disease by a lack of its antioxidant activities of PON-1 and ARYL. The results of this study were in agreement with those of earlier studies, which suggested that changes in antioxidant defence were caused by reduced oestrogen concentrations seen along with menopause. Even if our study cohort was small, we humbly demonstrated the risk that might lead some of the major metabolic disorders in the postmenopausal period. Further comprehensive studies with a larger population are necessary for a better understanding of the risks that women encounter in the postmenopausal period.

Acknowledgement: We highly acknowledge the grant of permission by Dr. Muhammad Marwat (marwatmuhammad@gmail.com) from Gomal Medical College, D.I.Khan, Pakistan to use his innovated "Marwat's Logical Trajectory of Research Process" in our project and further his help in data analysis and report writing.

\section{REFERENCES}

1. Dalal PK, Agarwal M. Postmenopausal syndrome. Indian J Psychiatry 2015;57(Suppl 2):S222. https://doi.org/10.4103/0019-5545.161483

2. Siddle N, Sarrel P, Whitehead M. The effect of hysterectomy on the age at ovarian failure: identification of a subgroup of women with premature loss of ovarian function and literature review. Fertil Steril 1987;47(1):94-100. https://doi.org/10.1016/ S0015-0282(16) 49942-5

3. Greendale GA, Lee NP, Arriola ER. The menopause. Lancet 1999;353(9152):571-80. https:// doi.org/10.1016/S0140-6736(98)05352-5

4. Sánchez-Rodríguez MA, Zacarías-Flores M, Arronte-Rosales A, Correa-Muñoz E, Mendoza-Núñez VM. Menopause as risk factor for oxidative stress. Menopause 2012;19(3):361-7. https://doi.org/10.1097/gme.0b013e318229977d

5. Burger HG. The endocrinology of the menopause. Maturitas 1996;23(2):129-36. https://doi. org/10.1016/0378-5122(95)00969-8

6. Baltacıoğlu E, Akalın FA, Alver A, Balaban F, Ünsal M, Karabulut E. Total antioxidant capacity and superoxide dismutase activity levels in serum and gingival crevicular fluid in post-menopausal women with chronic periodontitis. J Clin Periodontol 2006;33(6):385-92. https://doi. org/10.1111/j.1600-051X.2006.00923.x

7. Carr AC, McCall MR, Frei B. Oxidation of LDL by myeloperoxidase and reactive nitrogen species: reaction pathways and antioxidant protection. Arterioscler Thromb Vasc Biol 2000;20(7):1716-23. https://doi.org/10.1161/01.ATV.20.7.1716

8. Behl C. Estrogen can protect neurons: modes of action. J Steroid Biochem Mol Biol 2002;83(15):195-7. https://doi.org/10.1016/S09600760(02)00271-6

9. Amrita J, Mahajan M, Bhanwer AJS, Mohan G. Oxidative stress: an effective prognostic tool for an early detection of cardiovascular disease in menopausal women. Biochem Res Int 2016;2016. https://doi.org/10.1155/2016/6157605

10. Basu S, Michaëlsson $\mathrm{K}$, Olofsson $\mathrm{H}$, Johansson $\mathrm{S}$, Melhus $\mathrm{H}$. Association between oxidative stress and bone mineral density. Biochem Biophys Res Commun 2001;288(1):275-9. https://doi. org/10.1006/bbrc.2001.5747

11. Vural P, Akgül C, Canbaz M. Effects of menopause and tibolone on antioxidants in postmenopausal women. Ann Clin Biochem 2005;42(3):220-3. https://doi.org/10.1258/0004563053857941

12. Ha BJ. Oxidative stress in ovariectomy menopause and role of chondroitin sulfate. Arch Pharm Res 2004;27(8):867-72. https://doi.org/10.1007/ BF02980181

13. Karakurt Ö, Çağııııı G, Akdemir R. Paraoksonaz ve Ateroskleroz. Turkiye Klin Cardiovasc Sci 2012;24(2):128-33.

14. Litvinov D, Mahini H, Garelnabi M. Antioxidant and anti-inflammatory role of paraoxonase 1: implication in arteriosclerosis diseases. N Am J Med Sci 2012;4(11):523. https://doi.org/10.4103/19472714.103310 
15. Bacchetti T, Ferretti G, Sahebkar A. The role of paraoxonase in cancer. Semin Cancer Biol 2019 Jun;56:72-86. https://doi.org/10.1016/j.semcancer.2017.11.013

16. Primo-Parmo SL, Sorenson RC, Teiber J, La Du $\mathrm{BN}$. The human serum paraoxonase/ arylesterase gene (PON1) is one member of a multigene family. Genomics 1996 May 1;33(3):498-507. https:// doi.org/10.1006/geno.1996.0225

17. Topçuoglu A, Uzun $H$, Aydin S, Kahraman N, Vehid S, Zeybek G, et al. The effect of hormone replacement therapy on oxidized low density lipoprotein levels and paraoxonase activity in postmenopausal women. Tohoku J Exp Med 2005 Jan;205(1):79-86. https://doi.org/10.1620/ tjem.205.79

18. Sahin M, Bobusoglu O, Yetim A, Ates F. Paraoxonase-1 and arylesterase levels in patients with ulcerative colitis. Arab J Gastroenterol 2019;20(1):14-8. https://doi.org/10.1016/j. ajg.2019.01.009

19. Erel O. A new automated colorimetric method for measuring total oxidant status. Clin Biochem 2005;38(12):1103-11. https://doi.org/10.1016/j. clinbiochem.2005.08.008

20. Erel O. A novel automated method to measure total antioxidant response against potent free radical reactions. Clin Biochem 2004;37(2):112-9. https:// doi.org/10.1016/j.clinbiochem.2003.10.014

21. Eckerson HW, Wyte CM, La Du BN. The human serum paraoxonase/ arylesterase polymorphism. Am J Hum Genet 1983;35(6):1126.

22. Altindag O, Erel O, Soran N, Celik H, Selek S. Total oxidative/ anti-oxidative status and relation to bone mineral density in osteoporosis. Rheumatol Int 2008;28(4):317-21. https://doi.org/10.1007/ s00296-007-0452-0

23. Klisic A, Kavaric N, Vujcic S, Spasojevic-Kalimanovska V, Kotur-Stevuljevic J, Ninic A. Total oxidant status and oxidative stress index as indicators of increased Reynolds Risk Score in postmenopausal women. Eur Rev Med Pharmacol Sci 2020;24(19):10126-33.

24. Zhao F, Guo L, Wang X, Zhang Y. Correlation of oxidative stress-related biomarkers with postmenopausal osteoporosis: a systematic review and meta-analysis. Arch Osteoporos 2021;16(1):4. https://doi.org/10.1007/s11657020-00854-w

25. Dikker O, Şahin M, Atar S, Bekpınar S. Examination of oxidative stress markers in women with postmenopausal osteoporosis. Turk J Osteoporos 2018;24:15-20. https://doi.org/10.4274/ tod.71501

26. Zovari F, Parsian H, Bijani A, Moslemnezhad A, Shirzad A. Evaluation of salivary and serum total antioxidant capacity and lipid peroxidation in postmenopausal women. Int $\mathrm{J}$ Dent 2020 Nov 17;2020:8860467. https://doi. org/10.1155/2020/8860467

27. Bednarek-Tupikowska G, Tupikowski K, Bidzińska
B, Bohdanowicz-Pawlak A, Antonowicz-Juchniewicz J, Kosowska B, et al. Serum lipid peroxides and total antioxidant status in postmenopausal women on hormone replacement therapy. Gynecol Endocrinol 2004;19(2):57-63. https://doi. org/10.1080/09513590412331272328

28. Kolesnikova L, Semenova N, Madaeva I, Suturina L, Solodova E, Grebenkina L, et al. Antioxidant status in peri- and postmenopausal women. Maturitas [Internet] 2015;81(1):83-7. https://doi. org/10.1016/j.maturitas.2015.02.264

29. Vassalle $C$, Sciarrino R, Bianchi S, Battaglia D, Mercuri A, Maffei S. Sex-related differences in association of oxidative stress status with coronary artery disease. Fertil Steril [Internet]. 2012;97(2):414-419.e2. Available at: https:// www.sciencedirect.com/science/article/pii/ S0015028211028214 https://doi.org/10.1016/j. fertnstert.2011.11.045

30. Auro K, Joensuu A, Fischer K, Kettunen J, Salo $\mathrm{P}$, Mattsson $\mathrm{H}$, vd. A metabolic view on menopause and ageing. Nat Commun [Internet] 2014;5(1):4708. https://doi.org/10.1038/ncomms5708

31. de Aloysio D, Gambacciani M, Meschia M, Pansini F, Modena AB, Bolis PF, et al. The effect of menopause on blood lipid and lipoprotein levels. Atherosclerosis 1999;147(1):147-53. https://doi. org/10.1016/S0021-9150(99)00315-9

32. Poehlman ET, Toth MJ, Ades PA, Rosen CJ. Menopause-associated changes in plasma lipids, insulin-like growth factor I and blood pressure: a longitudinal study. Eur J Clin Invest 1997;27(4):322-6. https://doi.org/10.1046/j.13652362.1997.1160662.x

33. Stevenson JC, Crook D, Godsland IF. Influence of age and menopause on serum lipids and lipoproteins in healthy women. Atherosclerosis [Internet] 1993;98(1):83-90. https://doi.org/10.1016/00219150(93)90225-J

34. Kilim SR, Chandala SR. A comparative study of lipid profile and oestradiol in pre-and post-menopausal women. J Clin Diagnostic Res 2013;7(8):1596. https://doi.org/10.7860/JCDR/2013/6162.3234

35. Mešalić L, Tupković E, Kendić S, Balić D. Correlation between hormonal and lipid status in women in menopause. Bosn J Basic Med Sci 2008;8(2):188. https://doi.org/10.17305/ bjbms.2008.2980

36. Igweh JC, Nwagha IU, Okaro JM. The effects of menopause on the serum lipid profile of normal females of South East Nigeria. Niger J Physiol Sci 2005;20(1):48-53.

37. Usoro CAO, Adikwuru CC, Usoro IN, Nsonwu AC. Lipid profile of postmenopausal women in Calabar, Nigeria. Pak J Nutr 2006;5(1):79-82. https:// doi.org/10.4314/msjm.v5i1.11036

38. Tunstall-Pedoe H. Myth and paradox of coronary risk and the menopause. Lancet 1998;351(9113):1425-7. https://doi.org/10.1016/ S0140-6736(97)11321-6 
39. Sutherland WHF, Manning PJ, de Jong SA, Allum AR, Jones SD, Williams SM. Hormone-replacement therapy increases serum paraoxonase arylesterase activity in diabetic postmenopausal women. Metab Exp 2001;50(3):319-24. https:// doi.org/10.1053/meta.2001.20201

40. Mogarekar MR, Kulkarni SK. Small dense low density lipoprotein cholesterol, paraoxonase 1 and lipid profile in postmenopausal women: quality or quantity? Arch Med Res [Internet] 2015;46(7):534-8. https://doi.org/10.1016/j.arcmed.2015.08.007

41. Kumru S, Aydin S, Aras A, Gursu MF, Gulcu F. Effects of surgical menopause and estrogen replacement therapy on serum paraoxonase activity and plasma malondialdehyde concentration. Gynecol Obstet Invest 2005;59(2):108-12. https:// doi.org/10.1159/000082647

42. Çavdaroğlu B, Köse N, Başkol G, Demir H. Evaluation of protein and lipid oxidative stress in the patients with postmenopausal osteoporosis. Dicle Med J 2014;41(1). 71-7. https://doi.org/10.5798/ diclemedj.0921.2014.01.0375

43. Zago V, Sanguinetti S, Brites F, Berg G, Verona J, Basilio F, et al. Impaired high density lipoprotein antioxidant activity in healthy postmenopausal women. Atherosclerosis [Internet] 2004;177(1):203-10. https://doi.org/10.1016/j. atherosclerosis.2004.07.011

44. Kabaroglu C, Mutaf I il, Boydak B, Özmen D, Habif S, Erdener D, et al. Association between serum paraoxonase activity and oxidative stress in acute coronary syndromes. Acta Cardiol 2004;59(6):606-11. https://doi.org/10.2143/
AC.59.6.2005242

45. Gaillard T, Parthasarathy S, Osei K. HDL dysfunctionality (paraoxonase) is worse in nondiabetic, postmenopausal African American than in white women. Diabetes Care 2011;34(2):e19-e19. https://doi.org/10.2337/dc10-1189

46. Butorac D, Ćelap I, Kačkov S, Robić V, Miletić T, Flegar Meštrić ZFM, et al. Paraoxonase 1 activity and phenotype distribution in premenopausal and postmenopausal women. Biochem Medica 2014;24(2):273-80. https://doi.org/10.11613/ BM.2014.030

47. Ain N, Khan S, Marwat M, Khan N, Ahmad I, Ramzan F, et al. Frequency, distribution and determinants of hypertension in adult stroke population of D.I.Khan Division, Pakistan. Gomal J Med Sci 2019 Jul-Sep; 17 (3):81-9. https://doi. org/10.46903/gjms/17.03.2076

48. Marwat M, Ahmad I, Ashiq F, Ali S, Zamir S, Rehman MU, et al. Frequency, distribution and determinants of diabetes mellitus in adult acute coronary syndrome population of D.I.Khan Division, Pakistan. Gomal J Med Sci 2019 OctDec; 17 (4):131-43. https://doi.org/10.46903/ gjms/17.04.2106

49. Khalid MK, Ahmad I, Khan MA, Sharjeel M, Irfan M. Marwat M. Distribution of pediatric cataracts by sex, age groups, laterality, type and presentation in population of D.I.Khan District, Pakistan. Gomal J Med Sci 2019 OctDec; 17 (3):123-30. https://doi.org/10.46903/ gjms/17.04.2025

$$
\begin{gathered}
\text { CONFLICT OF INTEREST } \\
\text { Authors declare no conflict of interest. } \\
\text { GRANT SUPPORT AND FINANCIAL DISCLOSURE } \\
\text { None declared. }
\end{gathered}
$$

\section{AUTHORS' CONTRIBUTION}

The following authors have made substantial contributions to the manuscript as under:

$$
\text { Conception or Design: } \quad \text { BSE, MY, FEK }
$$

Acquisition, Analysis or Interpretation of Data: $\quad$ BSE, MY, FEK, HY

Manuscript Writing \& Approval: $\quad$ BSE, MY, FEK, HY

All the authors agree to be accountable for all aspects of the work in ensuring that questions related to the accuracy or integrity of any part of the work are appropriately investigated and resolved. 